\title{
Association of serum Clara cell protein CC16 with respiratory infections and immune response to respiratory pathogens in elite athletes
}

Marcin Kurowski', Janusz Jurczyk², Marzanna Jarzębska', Sylwia Moskwa', Joanna S Makowska', Hubert Krysztofiak ${ }^{2}$ and Marek L Kowalski*

\begin{abstract}
Background: Respiratory epithelium integrity impairment caused by intensive exercise may lead to exercise-induced bronchoconstriction. Clara cell protein (CC16) has anti-inflammatory properties and its serum level reflects changes in epithelium integrity and airway inflammation. This study aimed to investigate serum CC16 in elite athletes and to seek associations of CC16 with asthma or allergy, respiratory tract infections (RTIs) and immune response to respiratory pathogens.
\end{abstract}

Methods: The study was performed in 203 Olympic athletes. Control groups comprised 53 healthy subjects and 49 mild allergic asthmatics. Serum levels of CC16 and IgG against respiratory viruses and Mycoplasma pneumoniae were assessed. Allergy questionnaire for athletes was used to determine symptoms and exercise pattern. Current versions of ARIA and GINA guidelines were used when diagnosing allergic rhinitis and asthma, respectively.

Results: Asthma was diagnosed in $13.3 \%$ athletes, of whom $55.6 \%$ had concomitant allergic rhinitis. Allergic rhinitis without asthma was diagnosed in $14.8 \%$ of athletes. Mean CC16 concentration was significantly lower in athletes versus healthy controls and mild asthmatics. Athletes reporting frequent RTIs had significantly lower serum CC16 and the risk of frequent RTIs was more than 2-fold higher in athletes with low serum CC16 (defined as equal to or less than $4.99 \mathrm{ng} / \mathrm{ml}$ ). Athletes had significantly higher anti-adenovirus lgG than healthy controls while only non-atopic athletes had anti-parainfluenza virus lgG significantly lower than controls. In all athletes weak correlation of serum CC16 and anti-parainfluenza virus lgG was present $(R=0.20, p<0.01)$. In atopic athletes a weak positive correlations of CC16 with IgG specific for respiratory syncytial virus $(R=0.29, p=0.009)$, parainfluenza virus $(R=0.31, p=0.01)$ and adenovirus $(R=0.27, p=0.02)$ were seen as well.

Conclusions: Regular high-load exercise is associated with decrease in serum CC16 levels. Athletes with decreased CC16 are more susceptible to respiratory infections. Atopy may be an additional factor modifying susceptibility to infections in subjects performing regular high-load exercise.

Keywords: Respiratory viruses, Clara cell protein, Club cell protein, Exercise training, Asthma, Allergy

\section{Background}

Strenuous exercise characteristic of endurance sports is believed to have a detrimental effect on the integrity of the structure of the respiratory epithelium. Such damage may lead to increased bronchial hyperresponsiveness to non-specific stimuli and contribute to the increased

\footnotetext{
*Correspondence: marek.kowalski@csk.umed.lodz.pl

'Department of Immunology, Rheumatology and Allergy, Medical University of Łódź, ul. Pomorska 251, bud. C-5, Łódź 92-213, Poland

Full list of author information is available at the end of the article
}

prevalence of exercise-induced bronchoconsriction observed in elite endurance athletes [1-4]. Endurance sports may be also associated with increased susceptibility to respiratory infections [5], which in turn, may exert a destructive effect on the airway epithelium.

Various proteins have been assessed as potentially useful tools in monitoring airway inflammation and epithelial damage [6-9]. Clara cell secretory protein (CC16), a protein secreted by non-ciliated cells of the bronchioles, has also been studied as an indicator of epithelial barrier

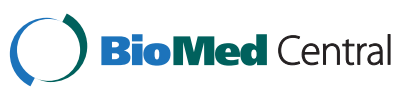


disruption in the lower airways. Significant efforts have been undertaken to explain its role in airway inflammation and, although its function has not been fully elucidated, CC16 is known to have anti-inflammatory and anti-oxidative properties [10]. However, CC16 levels in serum depend not only on its production by Clara cells and possible leakage through the disrupted epithelial barrier, but also on renal clearance. Moreover, multiple factors may influence final CC16 serum concentration (e.g., diurnal variation, age, ethnicity, atmospheric conditions, allergen exposure, exercise). As a result of these concerns the utility of serum CC16 level measurements in monitoring of the activity of pulmonary disease, airway inflammation and chronic or acute epithelial damage is disputed (reviewed by LaKind et al. [11]).

Changes in serum CC16 levels were observed after acute, short-lasting exposure to exercise or provocative or irritating stimuli. Non-specific challenges with exercise and eucapnic voluntary hyperpnea $(\mathrm{EVH})$ resulted in increased urinary CC16 levels $[12,13]$. In adult swimmers, exposure to trichloramine, a by-product of swimming pool disinfection, caused transient increase in serum CC16 levels while no such changes were observed in children [14].

Chronic airway inflammation may also be associated with shifts in local and systemic presence of CC16. During pollen season, CC16 in nasal lavage fluid is decreased in subjects with birch pollen-induced allergic rhinitis [15]. Decreases in serum CC16 levels in asthmatics are independent of their atopic status and correlate positively with duration of disease [16]. CC16 is believed to have not only immunomodulatory and antiinflammatory properties but also to possibly influence the anti-infectious response: an increased persistence of viruses and prolonged viral-specific gene expression were observed in CC16-deficient mice in response to RSV infection [17].

The aim of this study was to investigate the airway epithelium inflammation and potential damage in competitive athletes, as reflected by changes in serum CC16 levels. Secondly, we sought to identify possible associations of serum CC16 level with pattern of exercise, asthma or allergy, frequent respiratory infections and the immune response to respiratory pathogens reflected by pathogenspecific IgG levels in the serum.

\section{Materials and methods Subjects}

The study group consisted of 203 athletes (142 males and 61 females) preparing for the Olympic Games in Beijing in 2008 who were included into Allergy and Asthma in Polish Olympic Athletes study ( $\mathrm{A}^{2} \mathrm{POLO}$ ) which was a part of the multicentre Olympic Study performed within the framework of GA ${ }^{2}$ LEN (Global Allergy and Asthma European Network of Excellence project). One hundred and forty-six (71.9\%) of the recruited athletes were eventually included into the Polish Olympic Team for the Beijing games. The athletes represented 21 sport disciplines which, according to the predominant pattern of exercise, were divided into endurance (80 athletes) and non-endurance (123 athletes) (Table 1).

The protocol of the study was approved by the Bioethics Commission of the Medical University of Lodz. All subjects gave written informed consent for participation.

Bronchial asthma and allergic rhinitis were diagnosed based on criteria published in their respective Global Initative for Asthma (GINA) and Allergic Rhinitis and its Impact on Asthma (ARIA) guidelines [18,19].

Two control groups of subjects who had never performed sport at a competitive level were recruited as a reference for serum concentrations of lung specific protein. The first group consisted of 53 healthy subjects without history of allergy or any pulmonary condition whereas the second control group comprised 49 allergic non-smoking mild asthmatics with well controlled symptoms, diagnosed according to GINA [18] and receiving

\begin{tabular}{|c|c|}
\hline Sport & $\begin{array}{l}\text { Number of } \\
\text { athletes }\end{array}$ \\
\hline \multicolumn{2}{|l|}{ Endurance sports $(n=80)$} \\
\hline Cycling, mountain biking & 11 \\
\hline Rowing & 20 \\
\hline Canoe, kayak & 33 \\
\hline Modern pentathlon & 8 \\
\hline Triathlon & 3 \\
\hline Swimming & 5 \\
\hline \multicolumn{2}{|l|}{ Non-Endurance sports $(n=123)$} \\
\hline Volleyball & 19 \\
\hline Handball & 22 \\
\hline Weightlifting & 8 \\
\hline Fencing & 8 \\
\hline Gymnastics & 2 \\
\hline Badminton & 5 \\
\hline Shooting & 6 \\
\hline Judo & 7 \\
\hline Boxing & 2 \\
\hline Wrestling & 3 \\
\hline Track and field (except triathlon and modern pentathlon) & 14 \\
\hline Archery & 7 \\
\hline Tennis & 6 \\
\hline Sailing & 10 \\
\hline Windsurfing & 4 \\
\hline
\end{tabular}


anti-inflammatory treatment on a permanent basis. More detailed characteristics of the study and control groups are shown in Tables 2 and 3.

The following subgroups of athletes were distinguished for the purpose of further analysis: athletes diagnosed with allergic rhinitis $(\mathrm{n}=30)$; athletes diagnosed with allergic asthma with or without concomitant rhinitis $(n=27)$; and athletes without asthma or allergy $(n=146)$, basing on the diagnosis established during clinical evaluation of athletes. The data from an Allergy Questionnaire for Athletes (AQUA) were analysed separately.

\section{AQUA questionnaire}

Data regarding type of sport, allergy symptoms and history of respiratory infections, as well as demographical data, were acquired from the Allergy Questionnaire in Athletes (AQUA@) which was filled by each athlete entering the study. The AQUA questionnaire, developed and validated by Bonini et al [20] in Italian soccer players, is intended as an allergy screening tool in competitive athletes, with AQUA॰ score values $\geq 5$ described as having the best positive predictive value for allergy. The questionnaire is protected by copyright and its use in this study was kindly permitted by the authors.

\section{Lung function tests}

Spirometry was performed according to criteria defined by a joint ERS/ATS task force [21] using a Lungtest 1000 spirometer (MES, Kraków, Poland). Subjects receiving antiasthmatic treatment were asked to suspend taking long-acting beta2-agonists for 24 hours, shortacting beta2-agonists for 12 hours, inhaled steroids for 7 days and leukotriene modifiers for 5 days before lung function testing. At least three measurements in the upright position were performed and the best result was recorded. Reversibility test with bronchodilator was performed only in athletes. For this purpose, $400 \mu \mathrm{g}$ of salbutamol was administered by metered dose inhaler, followed by spirometry measurement 15 minutes later.
Changes in forced expiratory volume in $1 \mathrm{~s}(\triangle \mathrm{FEV} 1)$ from before to after drug inhalation were calculated according to the formula: $100 \times$ (postsalbutamol FEV1 initial FEV1)/initial FEV1.

\section{Laboratory measurements}

Serum samples were obtained from $86 \%(\mathrm{n}=119)$ nonendurance and $94 \%(n=75)$ endurance athletes. The remaining athletes were not available for blood sampling due to training schedules. Blood was drawn into Monovette tubes for serum (Sarstedt, Landskrona, Sweden). Each sample was left to clot at room temperature for ca. 30 minutes. Subsequently, samples were centrifuged at $700 \mathrm{~g}$ for 10 minutes and serum was transferred to cryotubes and frozen at $-80^{\circ} \mathrm{C}$ for further analyses.

CC16 concentration was determined using Human Clara Cell Protein ELISA kits (BioVendor Laboratory Medicine, Inc., Modrice, Czech Republic) in accordance with instructions provided by the manufacturer. Samples were run in duplicate at a 25 -fold dilution, following the manufacturer's recommendations. The lower CC16 detection limit is $20 \mathrm{pg} / \mathrm{ml}$.

The serum concentration of IgG antibodies against parainfluenza virus 1,2 and 3 (PIV) was determined by commercially available ELISA kit (DRG International, Inc., Mountainside, NJ, USA). The threshold value for positive anti-PIV IgG testing was $10 \mathrm{U} / \mathrm{ml}$.

The serum concentrations of IgG against respiratory syncytial virus (RSV), adenovirus and Mycoplasma pneumoniae were determined by commercially available semiquantitative ELISA kits (Orgenium Laboratories, Vantaa, Finland) The threshold value for positive testing was 25 Enzyme Immunoassay Units (EIU).

Concentrations of serum IgG's against repiratory pathogens were determined in athletes and healthy control groups only.

\section{Statistics}

Statistical analyses were performed using Statistica (Statsoft Polska, Krakow, Poland) and GraphPad Prism (Graphpad

Table 2 Demographics and lung function parameters in healthy and asthmatic control subjects and in athletes

\begin{tabular}{|c|c|c|c|c|c|}
\hline & Healthy controls & Asthma controls & All athletes & Endurance athletes & Non-endurance athletes \\
\hline No. of subjects & 53 & 49 & 203 & 80 & 123 \\
\hline Males/Females & $23 / 30$ & $15 / 34$ & $142 / 61$ & $60 / 20$ & $82 / 41$ \\
\hline Age[years] (median; range) & $28(20-45)$ & $29(18-45)$ & $26(18-41)$ & 25 & 26 \\
\hline $\begin{array}{l}\text { Baseline FEV1 [\% predicted] } \\
\text { (median;range) }\end{array}$ & $110(77-126)$ & $100(75-123)$ & $103(66-129)$ & $106(82-126)$ & $100(66-129)$ \\
\hline $\begin{array}{l}\Delta \mathrm{FEV} 1 \text { post-salbutamol [\%] } \\
\text { (median; range) }\end{array}$ & ND & ND & $4(0-26)$ & $4(0-20)$ & $4(0-26)$ \\
\hline $\begin{array}{l}\text { MEF } 25-75 \text { [\% predicted] } \\
\text { (median; range) }\end{array}$ & 104 & $80^{*}$ & $97(38-170)$ & $96(42-170)$ & $98(38-163)$ \\
\hline
\end{tabular}


Table 3 Demographics and lung function parameters in healthy and allergic athletes

\begin{tabular}{llll}
\hline & Athletes with rhinitis & Athletes with asthma & Athletes without asthma or allergy \\
\hline No. of subjects & 30 & 27 & 146 \\
Males/Females & $19 / 11$ & $17 / 10$ & $97 / 41$ \\
Age[years] (median; range) & 26 & 25 & 26 \\
Baseline FEV1 [\% predicted] (median;range) & $105(80-129)$ & $99(66-117)$ & $103(81-125)$ \\
SFEV1 post-salbutamol [\%] (median; range) & $4(0-10)$ & $10.5(2-26)^{\mathrm{a}}$ & $4(0-20)$ \\
FVC [\% predicted] (median; range) & $101(92-120)$ & $108(77-125)$ & $106.5(85-134)$ \\
FEV1/FVC (median; range) & $0.81(0.72-0.92)$ & $0.77(0.63-0.86)$ & $0.81(0.61-0.97)$ \\
MEF 25-75 [\% predicted] (median; range) & $98(54-156)$ & $82(38-122)^{\mathrm{b}}$ & $99(42-170)$
\end{tabular}

${ }^{a} p<0.001$ vs. athletes with rhinitis and athletes without asthma or allergy;

${ }^{b} \mathrm{p}<0.05$ vs. athletes with rhinitis and athletes without asthma or allergy.

Software, Inc., La Jolla, CA, USA) software. The Kolmogorov-Smirnov test with Lilliefors correction was used to check for normality of values' distribution. To identify differences between groups, the Mann-Whitney $U$ test or Kruskal-Wallis test with Dunn's post hoc test were used where applicable. Correlations of age, total $\mathrm{IgE}$, lung function parameters, reversibility challenge results and levels of IgG against respiratory pathogens with serum CC16 level were assessed with Spearman's rank correlation test.

The chi-square test with Yates' correction was used for between-the-group comparisons of percentage of positive tests for IgG against the presence of PIV, RSV, adenovirus or M. pneumoniae.

Relationships between serum CC16 level and AQUA score value with the presence of asthma/allergy symptoms and frequent respiratory infections were analysed using logistic regression.

A $P$ value less than 0.05 was considered statistically significant in all analyses.

\section{Results}

\section{Clinical features}

Upon clinical evaluation, asthma was diagnosed in 27 athletes (13.3\%) of whom $15(55.6 \%)$ had concomitant allergic rhinitis, whereas allergic rhinitis (without concomitant asthma) - in 30 subjects (14.8\%).

An affirmative answer to the question "Do you frequently suffer from upper respiratory infections (pharyngitis, bronchitis, colds) or fever?" was given by 39 athletes (19.2\%). No differences in the prevalence of selfreported frequent infections were seen between atopic and non atopic athletes (20.1\% vs. $18.4 \%$; $p>0.05, X^{2}$ test).

Lung function parameters did not differ significantly between endurance and non-endurance athletes. No differences were observed between athletes (endurance and non-endurance) and any of the control groups - Table 2. The median FEV1, FVC and FEV1/FVC values in asthmatic athletes were not significantly different from those observed in athletes with rhinitis and in non-asthmatic non-allergic athletes. Median MEF25-75 values were significantly lower in athletes with asthma as compared to other athletes. Also, MEF25-75 values were significantly reduced in asthmatic controls compared to the healthy controls and the athletes - Table 2. The percentage increase in FEV1 after salbutamol was significantly higher in athletes with asthma than in non-asthmatics $(10.5 \%$ vs $4 \%$; $\mathrm{p}<0.001)$ - Table 3 .

\section{Serum $\mathrm{CC} 16$ and exercise pattern}

Serum CC16 concentration was measured in 75 endurance and 123 non-endurance athletes and in two control groups of non-athletes. The mean serum CC16 concentration was significantly lower in the "all-athletes" group than in healthy controls and asthmatic controls Figure 1. No differences in the serum CC16 concentrations were observed between endurance and non-endurance athletes (7.13 [5.09-9.43] vs. 6.67 [5.20-9.14] ng/ml; medians with interquartile ranges, $\mathrm{p}>0.05]$ ). Considering possible noxious effect of trichloramines on airway epithelium and Clara cell function, additional analysis was performed to assess possible influence of competitive swimming on serum CC16 levels. Exclusion of swimmers and triathletes $(\mathrm{n}=8)$ did not significantly influence the serum CC16 level (6.79 [5.17-9.18] ng/ml without swimmers and triathletes vs. 6.82 [5.14-9.17] $\mathrm{ng} / \mathrm{ml}$ in all athletes; medians with interquartile ranges, $\mathrm{p}>0.05$, Mann-Whitney $U$ test).

\section{Serum CC16, allergic disease and respiratory infections}

Levels of serum CC16 did not differ significantly between atopic and non-atopic athletes (6.88 [5.37-9.15] vs. 6.68 [5.03-9.06] $\mathrm{ng} / \mathrm{ml}$; medians with interquartile ranges, $\mathrm{p}>0.05]$ ). No association was found between CC16 levels and self-reported asthma symptoms or between serum CC16 and physician-diagnosed asthma or allergic rhinitis. However, in athletes reporting frequent upper respiratory infections, the median serum $\mathrm{CC} 16$ levels were 


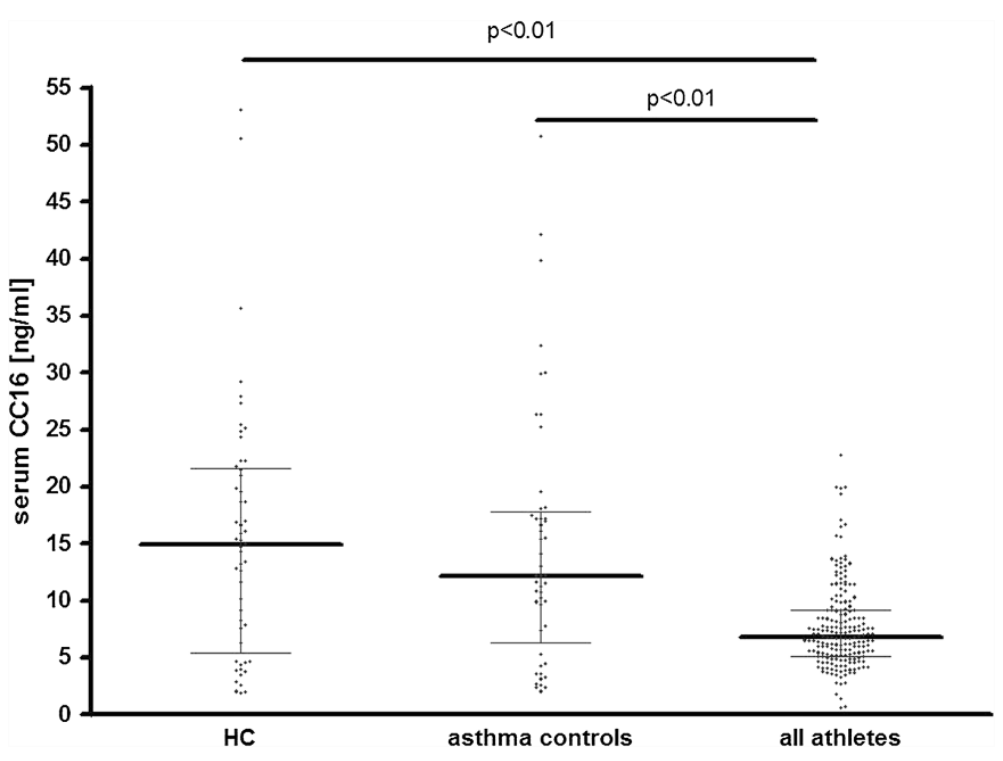

Figure 1 Serum Clara cell protein (CC16) concentration in healthy controls (HC), mild asthmatic controls and in athletes. One dot represents one subject. Medians with interquartile ranges are marked with horizontal lines.

significantly lower than in the remaining athletes (median values 5.57 vs $7.03 \mathrm{ng} / \mathrm{ml}$; respectively, $\mathrm{p}=0.01$, MannWhitney $U$ test) - Figure 2 .

No significant correlation of serum CC16 with asthma, baseline FEV1 or percentage of airway reversibility after beta-agonist treatment was found in the all-athletes group or in any of the athlete subgroups: ie, endurance, non-endurance, allergic/asthmatic or healthy athletes. Similarly, no correlations of serum CC16 with age or lung function parameters were found in the control groups.
Logistic regression analysis using 'serum CC16 $\leq$ $4.99 \mathrm{ng} / \mathrm{ml}$ ' (considered as the low value) as an independent variable showed that the risk of frequent URTIs, as reported in the AQUA questionnaire, was significantly higher in athletes with low serum CC16 (OR $=2.56$; 95\% CI:1.19-5.50; $\mathrm{p}<0.02)$. Also, the risk of declared nasal symptoms, not identical with physician-diagnosed rhinitis, was higher in athletes with serum CC16 $\leq 4.99 \mathrm{ng} / \mathrm{ml}$ $(\mathrm{OR}=2.21 ; 95 \% \mathrm{CI}: 1.10-4.47 ; \mathrm{p}<0.03)$.

No association was found between a serum CC16 level lower than $4.99 \mathrm{ng} / \mathrm{ml}$ and diagnosis of allergic rhinitis,

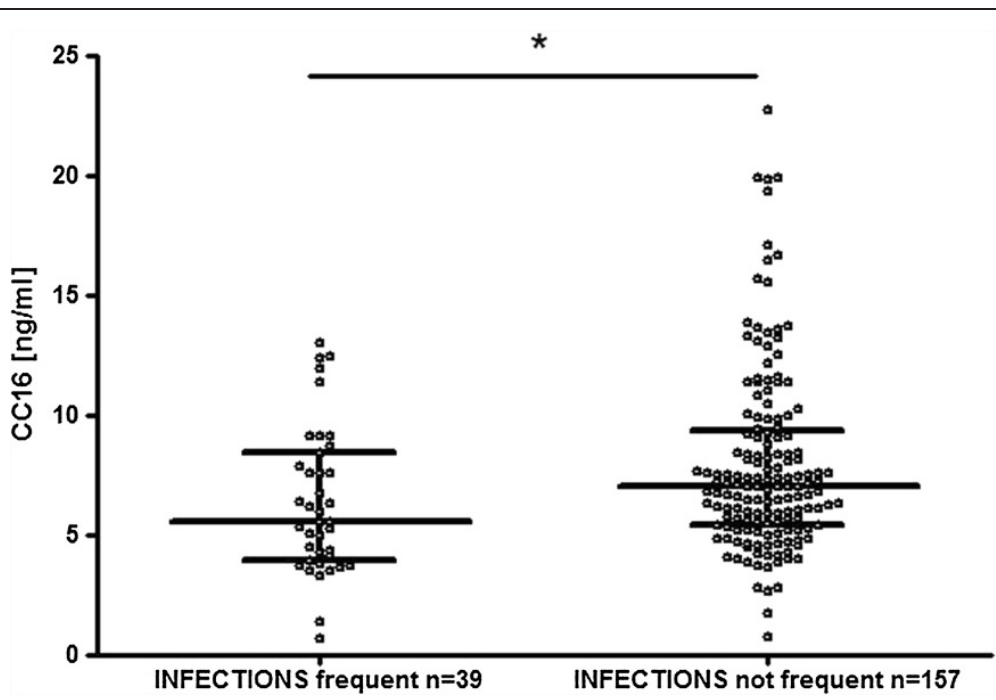

Figure 2 Serum CC16 levels in athletes reporting and not reporting frequent respiratory infections when completing the AQUA $\odot$ questionnaire. Medians with interquartile ranges are marked with horizontal lines. One dot represents one subject. * $p=0.01$, Mann Whitney $U$ test. 
diagnosis of asthma, declared cough and/or dyspnoea without physician-confirmed asthma, presence of atopy or positive serological test for any respiratory pathogen. Logistic regression analysis using 'serum CC16 $\leq 4.99 \mathrm{ng} / \mathrm{ml}$ ' as a dependent variable did not show decreased serum CC16 levels to be determined either by predominant endurance exercise nor by length of the single training session.

\section{Serum IgG immune response to respiratory pathogens}

The prevalence of positive serological testing for antiPIV, anti-RSV or and anti- M.pneumoniae (but not for antiadenovirus) antibody, was significantly lower among athletes than among healthy subjects. The mean serum concentration of Anti-PIV IgG levels was significantly lower, whereas concentration of anti-AdV IgG was significantly higher in professional athletes - Table 4.

The percentage of positive serological tests and median serum levels of IgG against respiratory pathogens did not differ between athletes declaring frequent URTIs in AQUA questionnaire and the remaining group Table 5.

\section{Correlations of serum CC16 and IgG immune response to respiratory pathogens}

In all athletes, a weak yet significant positive correlation of serum CC16 and IgG concentration was observed only for PIV $(R=0.20, p<0.01)$ but not for the remaining pathogens. In atopic athletes, positive correlations were observed between the levels of serum CC16 and IgG against RSV $(R=0.29, p=0.009)$, PIV $(R=0.31, p=0.01)$ and Adenovirus $(R=0.27, p=0.02)$. No significant correlations were observed in healthy controls.

Higher anti-adenovirus IgG titres were found in both atopic and non-atopic athletes as compared to HC (46.4 [23.5-64.8] and 41.6 [25.4-53.3] vs 33.4 [25.8-41.2] EIU, respectively; median [interquartile range], $\mathrm{p}<0.001$ ) Figure 3A. Non-atopic athletes had lower anti-PIV IgG levels than atopic athletes (65.9 [22.6-96.5] vs 88.1 [62.8107.6] $\mathrm{U} / \mathrm{ml}$; median [interquartile range], $\mathrm{p}<0.01$ ), and lower than HC (65.9 [22.6-96.5] vs 104.8 [68.5126.0] U/ml; median [interquartile range], $\mathrm{p}<0.001$ ) Figure 3B. No significant differences between atopic and non-atopic athletes and $\mathrm{HC}$ were seen with regard to
anti-RSV and anti-Mycoplasma pneumoniae IgG levels (data not shown).

When the results of the positive serological testing were analysed, a significantly lower percentage of subjects with positive anti-RSV serology was observed in non atopic athletes $(60.8 \%)$ than in healthy controls (84.4\%, $\mathrm{p}=0.001)$ and atopic athletes $(76.3 \%, \mathrm{p}=0.03)$. The presence of a positive RSV serology test was significantly associated with atopy $(\mathrm{OR}=2.89 ; 95 \% \mathrm{CI}, 1.34-6.23$; $\mathrm{p}=0.007$ ). Such associations were not observed regarding serological testing for IgG against PIV, adenovirus and M. pneumoniae - data not shown.

\section{Discussion}

This study documents that serum CC16 concentrations are significantly lower in top athletes than in control subjects from the general population. Decreased serum CC16 concentrations were reported in infants and children regularly visiting indoor pools [22,23] but other studies brought conflicting results regarding the effect of single and repeated training session on serum CC16 $[24,25]$. Discrepancies are believed to be due to intensity of exertion and breathing pattern employed during various types of athletic activity (reviewed by LaKind et al. [11]). Our study, including large and heterogeneous group has shown decreased serum CC16 levels in professional athletes, irrespective of the type or pattern of high-level activity. However, due to the limited number of athletes representing each discipline, it was impossible to assess the influence of each type of sport on serum CC16 concentration. We have not ascertained any influence of predominant exercise pattern (endurance versus non-endurance) on athletes' serum CC16 levels. Although withdrawal of swimmers and triathletes from the serum CC16 analysis did not influence final result, these data - in our opinion - are too scarce to conclude that unfavourable training environment (e.g., trichloramine exposure) does not affect serum CC16 concentration.

CC16 is a protein of multifaceted characteristics. It may be considered both as a marker of the disruption of airway epithelial barrier integrity and as a co-participant in antiinflammatory response. Degree of CC16 involvement and

Table 4 Percentage of positive test results and levels of IgG against respiratory pathogens in healthy controls (HC) and olympic-level athletes

\begin{tabular}{|c|c|c|c|c|c|c|}
\hline \multirow[t]{2}{*}{ Pathogen } & $\mathrm{HC}$ & Athletes & \multirow{2}{*}{$\begin{array}{l}P \text { value } \\
{\left[X^{2} \text { test }\right]}\end{array}$} & $\mathrm{HC}$ & Athletes & \multirow{2}{*}{$\begin{array}{l}\text { P value } \\
\text { [Mann-Whitney } U \text { test }\end{array}$} \\
\hline & \multicolumn{2}{|c|}{ Percentage of positive serological tests } & & \multicolumn{2}{|c|}{ median IgG level } & \\
\hline PIV 1,2,3 & $95.7 \%$ & $74.7 \%$ & $<0.0003$ & $99.5 \mathrm{U} / \mathrm{ml}$ & $32.9 \mathrm{U} / \mathrm{ml}$ & $<0.0001$ \\
\hline RSV & $84.4 \%$ & $68.2 \%$ & 0.01 & 39.7 EIU & 35.3 EIU & 0.25 \\
\hline AdV & $72.7 \%$ & $71.3 \%$ & 0.93 & 33.4 EIU & 44.2 EIU & 0.0005 \\
\hline M. pneumoniae & $100 \%$ & $90.2 \%$ & 0.01 & 66.3 EIU & 65.2 EIU & 0.38 \\
\hline
\end{tabular}

PIV, parainfluenza virus; RSV, respiratory syncytial virus; AdV, adenovirus. Significant $P$ values given in bold print. 
Table 5 Percentage of positive test results and levels of IgG against respiratory pathogens in athletes with and without frequent upper respiratory tract infections (URTIs)

\begin{tabular}{lllllll}
\hline Pathogen & $\begin{array}{l}\text { Athletes with } \\
\text { frequent URTIs } \\
\text { Percentage of positive serological tests }\end{array}$ & $\begin{array}{l}\text { Athletes without } \\
\text { frequent URTIs }\end{array}$ & $\begin{array}{l}\text { P value } \\
{\left[X^{2} \text { test] }\right.}\end{array}$ & $\begin{array}{l}\text { Athletes with } \\
\text { frequent URTIs } \\
\text { Median lgG level }\end{array}$ & $\begin{array}{l}\text { Athletes without } \\
\text { frequent URTIs }\end{array}$ & $\begin{array}{l}\text { P value } \\
\text { [Mann-Whitney } U \text { test] }\end{array}$ \\
\hline PIV 1,2,3 & $47.2 \%$ & $52.6 \%$ & 0.70 & $25.4 \mathrm{U} / \mathrm{ml}$ & $33.0 \mathrm{U} / \mathrm{ml}$ & 0.17 \\
RSV & $71.8 \%$ & $67.5 \%$ & 0.75 & $32.8 \mathrm{EIU}$ & $35.3 \mathrm{EIU}$ & 0.66 \\
AdV & $66.7 \%$ & $72.7 \%$ & 0.58 & $43.9 \mathrm{EIU}$ & $44.3 \mathrm{EIU}$ & 0.66 \\
M. pneumoniae & $92.3 \%$ & $90.9 \%$ & 0.96 & $64.3 \mathrm{EIU}$ & $65.7 \mathrm{EIU}$ & 0.64 \\
\hline
\end{tabular}

PIV, parainfluenza virus; RSV, respiratory syncytial virus; AdV, adenovirus.

significance in the aforementioned processes is still a matter of research and dispute.

Our results suggest, that it is an intensive and regularly performed exercise per se that stimulates airway inflammation, irrespective of training intensity.
Reduced presence of CC16, an anti-inflammatory factor, may additionally contribute to airway inflammation and hyperresponsiveness.

In addition, the control non-athletes asthmatic patients were found to have CC16 levels similar to those in

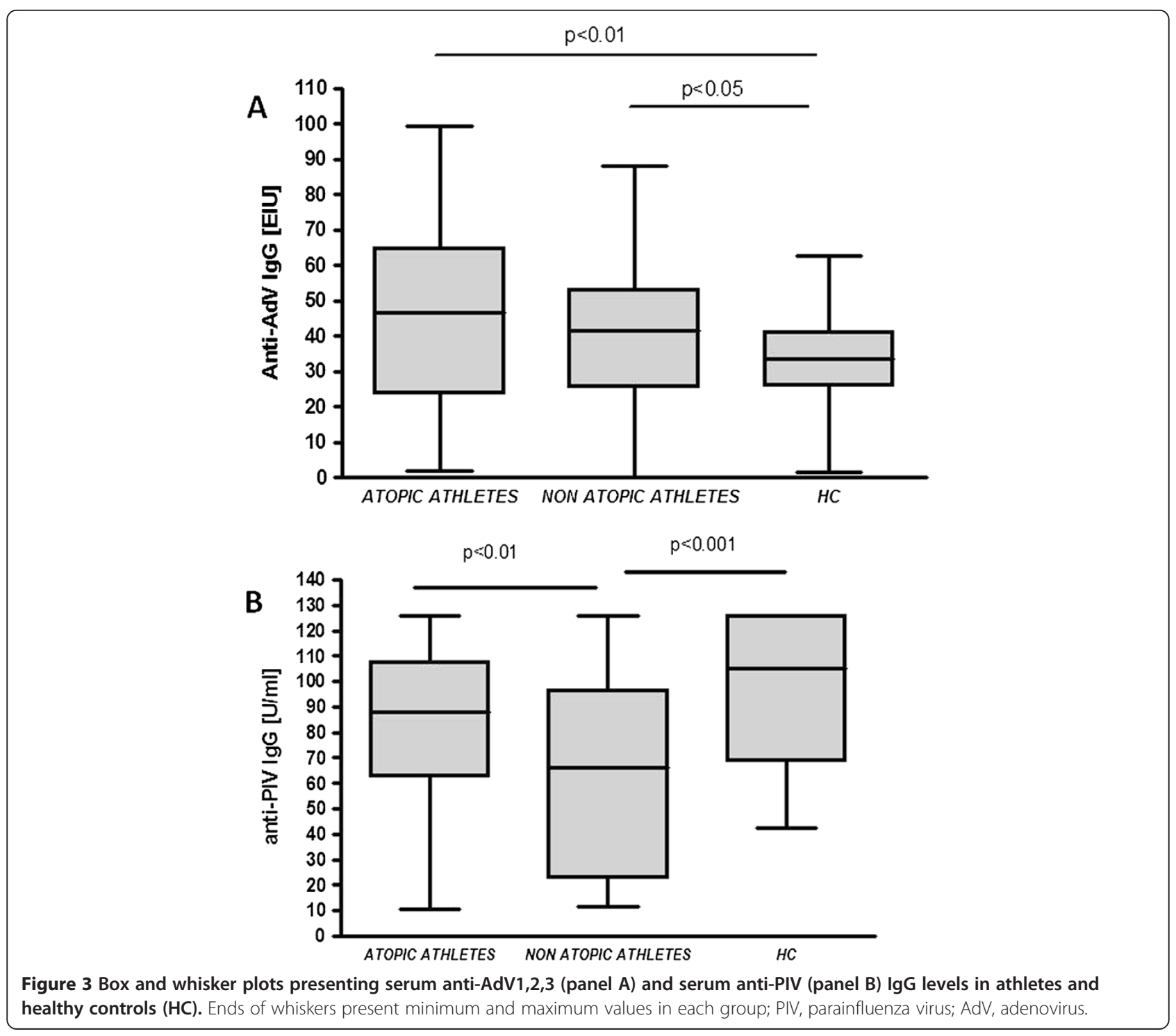


healthy controls, which contrasts with the results of other report, documenting a significant decrease of serum CC16 in asthma [16]. In our opinion, the possible explanation for this discrepancy is the fact that our asthmatic controls group comprised exclusively subjects with mild disease well controlled on anti-inflammatory treatment. Therefore, it is possible that that changes in serum CC16 level reflect the grade of airway inflammation in asthma, similarly as it was observed in regard to sputum CC16 in subjects with COPD [26]. Our data suggest that the issue of CC16 in chronic asthma be extensively studied in a welldefined population.

Although recent data published by Jacobs et al [27] show that lower serum CC16 levels may be associated with allergic sensitisation, no differences in CC16 levels between atopics and non-atopics were observed in our population of athletes. Therefore, the associations of allergic sensitisation with markers of epithelial barrier disruption require further study.

Another novel observation is that athletes declaring frequent upper respiratory tract infections had significantly lower serum CC16 concentrations than those without frequent infections - Figure 2. Accordingly, a higher risk of frequent respiratory infections was associated with low serum CC16 level. Low serum CC16 was found to be also associated with patients' reported symptoms of rhinitis, but not with physician-diagnosed rhinitis. This apparent discrepancy may be explained by the fact that symptoms declared as "rhinitis" were, in fact, symptoms of upper respiratory infections. This is congruous with observation that both frequent of URTIs and reported rhinitis symptoms are considerably more likely to be encountered in athletes with serum CC16 below $5 \mathrm{ng} / \mathrm{ml}$.

The common belief that moderate exercise is beneficial to one's health whereas excessive physical training may considerably increase the susceptibility to infection was confirmed by the concept of the U-shaped relationship between physical activity and resistance to disease [5]. Our study comprised top-level athletes and, although only $19.2 \%$ of them claimed to be suffering from frequent respiratory infections, those who reported infections had significantly lower serum CC16 concentrations. This interaction is further strengthened by significant associations of decreased serum CC16 levels with frequent declared respiratory infections and nasal symptoms and indicates, that the immune response against some respiratory pathogens may be modified by competitive sporting activity. Positive correlation of antiPIV IgG and serum CC16 may be considered an indirect proof for immunomodulatory activity of the latter, but the lack of such correlation for the remaining pathogens is somewhat puzzling and suggests the need for further study of the influence of CC16 on the susceptibility to infection with particular pathogens.
Less frequent positive serological test results against PIV, RSV and M. pneumoniae in professional athletes compared to controls may be interpreted as indirect evidence for impaired immunocompetence resulting from continuous high exercise load. In a mouse model, CC16 was shown to influence the lymphocyte response of the airways after infection with RSV. Mice lacking CC16 demonstrated significantly higher concentrations of Th2 cytokines IL-5 and IL-13 in BALF for several days following the infection [17]. The stimulatory activity of RSV infection on Th2 cytokine synthesis and release may explain the association of atopy with more frequent occurrence of positive testing for anti-RSV IgG in atopic athletes.

The frequency of positive immune response to RSV was comparable between atopic athletes and healthy control subjects, but it was significantly lower in nonatopic athletes. In addition, correlations between serum CC16 level and intensity of immune response to respiratory viruses (RSV, PIV and adenoviruses) were only significant in atopic athletes. Given that serum CC16 levels in athletes were not seen to be modified by atopy status, it may suggest, that atopy per se influences the immune response to respiratory viruses.

Our study has several limitations. The study group was quite heterogeneous in terms of predominant pattern of exercise and training environment not allowing for identification of possible effects of any particular sport on CC16 or immune response against respiratory pathogens. Accordingly, no standardised and comparable measures of exercise load/intensity could be included into analysis. Furthermore, the AQUA question concerning respiratory infections does not determine their actual frequency, allowing only for the subjective assessment of whether the URTIs are frequent or not.

Another limitation of our study results from the intersubject variability of CC16 levels. Overlaps in the serum CC16 are observed between the groups and it could be argued that outliers influence the overall result. Significant differences were shown through non-parametric tests which makes possibility of such influence less likely. However, this issue should be considered possible confounder and addressed in next studies on CC16 in larger populations.

For the purpose of logistic regression analysis, $5.0 \mathrm{ng} / \mathrm{ml}$ was set arbitrarily as the CC16 threshold value, based on the reference value given by the manufacturers of the ELISA kits. However, the CC16 levels in healthy subjects are variable and the accepted reference values for CC16 are actually lacking, which substantially hinders such analysis and signals the need for further assessment of CC16 levels in various clinical models $[7,24,28]$.

Bronchial hyperreactivity was assessed only in few patients (due to their training schedules and low accessibility) 
and could not be analysed in this study. However, of the role of CC16 in the context of bronchial hyperresponsiveness may be important for understanding the pathogenesis of EIB, especially in view of the data showing association of CC16 gene polymporphism with airway hyperresponsiveness and asthma phenotype [29].

\section{Conclusions}

Our study demonstrated that regular high-load exercise training is associated with a decrease in serum CC16 protein levels and lower CC16 levels in competitive athletes are associated with increased prevalence of reported respiratory infections. Further studies are necessary to elucidate the mechanism of association between increased susceptibility to respiratory infections in top athletes and epithelial cell injury markers such as CC16.

\section{Competing interests}

The authors declare they have no competing interests regarding this article.

\section{Authors' contributions}

MK and MLK participated in conception and design of the study, in analysis and interpretation of data, and in manuscript preparation; MK, $\mathrm{JJ}$ and HK participated in subjects' recruitment and clinical assessment; MJ and SM performed laboratory measurements; JSM recruited and assessed subjects from control groups. All authors read and approved the final manuscript.

\section{Author details}

'Department of Immunology, Rheumatology and Allergy, Medical University of Łódź, ul. Pomorska 251, bud. C-5, Łódź 92-213, Poland. ${ }^{2}$ National Centre for Sports Medicine (COMS), Warsaw, Poland.

\section{Received: 10 May 2013 Accepted: 7 March 2014}

Published: 15 April 2014

\section{References}

1. Helenius I, Rytilä P, Metso P, Haahtela T, Venge P, Tikkanen H: Respiratory symptoms, bronchial responsiveness, and cellular characteristics of induced sputum in elite swimmers. Allergy 1998, 53:346-352.

2. Helenius I, Tikkanen H, Sarna S, Haahtela T: Asthma and increased bronchial responsiveness in elite athletes: atopy and sport event as risk factors. J Allergy Clin Immunol 1998, 101:646-652.

3. Carlsen K: Sports in extreme conditions: the impact of exercise in cold temperatures on asthma and bronchial hyper-responsiveness in athletes. Br J Sports Med 2012, 46:796-799.

4. Carlsen K-H, Kowalski ML: Asthma, allergy, the athlete and the Olympics. Allergy 2008, 63:383-386.

5. Walsh N, Gleeson M, Shephard R, Gleeson M, Woods J, Bishop N, Fleshner M, Green C, Pedersen BK, Hoffman-Goetz L, Rogers CJ, Northoff H, Abbasi A, Simon P: Position statement. Part one: immune function and exercise. Exerc Immunol Rev 2011, 17:6-63.

6. Bougault V, Turmel J, St-Laurent J, Bertrand M, Boulet LP: Asthma, airway inflammation and epithelial damage in swimmers and cold-air athletes. Eur Respir J 2009, 33:740-746.

7. Font-Ribera L, Kogevinas M, Zock J, Gómez F, Barreiro E, Nieuwenhuijsen M, Fernandez P, Lourencetti C, Pérez-Olabarría M, Bustamante M, Marcos R, Grimalt JO, Villanueva CM: Short-term changes in respiratory biomarkers after swimming in a chlorinated pool. Environ Health Perspect 2010, 118:1538-1544.

8. Shorter J, Nelson D, McManus J, Zahniser M, Sama S, Milton D: Clinical study of multiple breath biomarkers of asthma and COPD (NO, CO(2), CO and N(2)O) by infrared laser spectroscopy. J Breath Res 2011, 5:037108. doi:10.1088/1752-7155/5/3/.
9. Braido F, Bagnasco D, Scichilone N, Santus P, Solidoro P, Di Marco F, Corsico A, Canonica GW: Biomarkers in obstructive respiratory diseases: an update. Panminerva Med 2012, 54:119-127.

10. Broeckaert F, Bernard A: Clara cell secretory protein (CC16): characteristics and perspectives as lung peripheral biomarker. Clin Exp Allergy 2000, 30:469-475.

11. LaKind J, Holgate S, Ownby D, Mansur A, Helms P, Pyatt D, Hays SM: A critical review of the use of Clara cell secretory protein (CC16) as a biomarker of acute or chronic pulmonary effects. Biomarkers 2007, 12:445-467.

12. Bolger C, Tufvesson E, Sue-Chu M, Devereux G, Ayres J, Bjermer L, Kippelen P: Hyperpnea-induced bronchoconstriction and urinary CC16 levels in athletes. Med Sci Sports Exerc 2011, 43:1207-1213.

13. Romberg K, Bjermer L, Tufvesson E: Exercise but not mannitol provocation increases urinary Clara cell protein (CC16) in elite swimmers. Resp Med 2011, 105:31-36.

14. Carbonnelle S, Francaux M, Doyle I, Dumont X, de Burbure C, Morel G, Michel $O$, Bernard $A$ : Changes in serum pneumoproteins caused by short-term exposures to nitrogen trichloride in indoor chlorinated swimming-pools. Biomarkers 2002, 7:464-478.

15. Benson M, Fransson M, Martinsson T, Naluai A, Uddman R, Cardell L: Inverse relation between nasal fluid Clara cell protein 16 levels and symptoms and signs of rhinitis in allergen-challenged patients with intermittent allergic rhinitis. Allergy 2007, 62:178-183.

16. Shijubo N, Itoh Y, Yamaguchi T, Sugaya F, Hirasawa M, Yamada T, Kawai T, Abe S: Serum levels of Clara cell 10-kDa protein are decreased in patients with asthma. Lung 1999, 177:45-52.

17. Wang S, Rosenberger C, Bao Y, Stark J, Harrod K: Clara cell secretory protein modulates lung inflammatory and immune responses to respiratory syncytial virus infection. J Immunol 2003, 171:1051-1060.

18. GINA Report, Global Strategy for Asthma Management and Prevention; 2011. Updated 2011. http://www.ginasthma.org/uploads/users/files/GINA_ Report2011_May4.pdf [accessed 23 June 2012].

19. Bousquet J, Schünemann H, Samolinski B, Demoly P, Baena-Cagnani C, Bachert C, Bonini S, Boulet LP, Bousquet PJ, Brozek JL, Canonica GW, Casale TB, Cruz AA, Fokkens WJ, Fonseca JA, van Wijk RG, Grouse L, Haahtela T, Khaltaev N, Kuna P, Lockey RF, Lodrup Carlsen KC, Mullol J, Naclerio R, O'Hehir RE, Ohta K, Palkonen S, Papadopoulos NG, Passalacqua G, Pawankar R: Allergic Rhinitis and its Impact on Asthma (ARIA): achievements in 10 years and future needs. J Allergy Clin Immunol 2012, 130:1049-1062.

20. Bonini M, Braido F, Baiardini I, Del Giacco S, Gramiccioni C, Manara M, Tagliapietra G, Scardigno A, Sargentini V, Brozzi M, Rasi G, Bonini S: AQUA: Allergy Questionnaire for Athletes. Development and validation. Med Sci Sports Exerc 2009, 41:1034-1041.

21. Miller M, Hankinson J, Brusasco V, Burgos F, Casaburi R, Coates A, Crapo R, Enright $P$, van der Grinten CP, Gustafsson P, Jensen R, Johnson DC, MacIntyre N, McKay R, Navajas D, Pedersen OF, Pellegrino R, Viegi G, Wanger J, ATS/ERS Task Force: Standardisation of spirometry. Eur Respir J 2005, 26:319-338.

22. Bernard A, Carbonnelle S, Dumont X, Nickmilder M: Infant swimming practice, pulmonary epiuthelium integrity, and the risk of allergic and respiratory diseases later in childhood. Pediatrics 2007, 119:1095-1103.

23. Lagerkvist B, Bernard A, Blomberg A, Bergstrom E, Forsberg B, Holmstrom K, Karp K, Lundstrom NG, Segerstedt B, Svensson M, Nordberg G: Pulmonary epithelial integrity in children: relationship to ambient ozone exposure and swimming pool attendance. Environ Health Perspect 2004, 112:1768-1771.

24. Carbonnelle S, Bernard A, Doyle I, Grutters J, Francaux M: Fractional exhaled NO and serum pneumoproteins after swimming in a chlorinated pool. Med Sci Sports Exerc 2008, 40:1472-1476.

25. Fernández-Luna A, Gallardo L, Plaza-Carmona M, García-Unanue J, SánchezSánchez J, Felipe J, Burillo P, Ara I: Respiratory function and changes in lung epithelium biomarkers after a short-training intervention in chlorinated vs. ozone indoor pools. PloS One 2013, 8:e68447.

26. Braido F, Riccio A, Guerra L, Gamalero C, Zolezzi A, Tarantini F, De Giovanni B, Folli C, Descalzi D, Canonica GW: Clara cell 16 protein in COPD sputum: a marker of small airways damage? Resp Med 2007, 101:2119-2124.

27. Jacobs J, Fuertes E, Krop E, Spithoven J, Tromp P, Heederik D: Swimming pool attendance and respiratory symptoms and allergies among Dutch children. Occup Environ Med 2012, 69:823-830. 
28. Broeckaert F, Clippe A, Knoops B, Hermans C, Bernard A: Clara Cell Secretory Protein (CC16): features as a peripheral lung biomarker. Ann N Y Acad SCi 2000, 923:68-77.

29. Sengler C, Heinzmann A, Jerkic S, Haider A, Sommerfeld C, Niggemann B, Lau S, Forster J, Schuster A, Kamin W, Bauer C, Laing I, LeSouef P, Wahn U, Deichmann K, Nickel R: Clara cell protein 16 (CC16) gene polymorphism influences the degree of airway responsiveness in asthmatic children. J Allergy Clin Immunol 2003, 111:515-519.

doi:10.1186/1465-9921-15-45

Cite this article as: Kurowski et al: Association of serum Clara cell protein $\mathrm{CC} 16$ with respiratory infections and immune response to respiratory pathogens in elite athletes. Respiratory Research 2014 15:45.

\section{Submit your next manuscript to BioMed Central and take full advantage of:}

- Convenient online submission

- Thorough peer review

- No space constraints or color figure charges

- Immediate publication on acceptance

- Inclusion in PubMed, CAS, Scopus and Google Scholar

- Research which is freely available for redistribution 